\title{
The Principal Managerial Competence In Improving Teachers Performance At State Junior High School 1 And State Junior High School 13 Of Banda Aceh
}

\author{
Muhaiyar $^{1}$, Yusrizal $^{2}$, Bahrun ${ }^{3}$ \\ \{muhaiyar999@gmail.com $\left.{ }^{1}\right\}$ \\ ${ }^{1)}$ Master of Education Administration. Graduate Program of Syiah Kuala University, Banda Aceh, \\ Indonesia \\ 2,3) Master of Education Administration. Graduate Program of Syiah Kuala University, Darussalam, \\ Banda Aceh 23111, Indonesia
}

\begin{abstract}
As a top manager in a school, A principal has a strategic role in improving teachers' performance. The aim of this research is to examine the program, strategy, and obstacle faced by the principal in improving the teachers' performance in the State Junior High School of Banda Aceh 1 and State Junior High School of Banda Aceh 13. This research uses the descriptive method with a qualitative approach. The techniques for collecting data used in this research are an interview, observation, and documentation. The subjects of this research are the principal, the vice principal, and teachers. The result shows that: (1) The principal program in improving the teachers' performance has been developed, but it is not in detail and well-planned. The programs are implemented by the principal to improve the teachers' performance; (2) the teacher performance improvement programs are done by applying the democratic leadership strategy; in the cooperation with teachers, the principal usually has discussion with teachers to find out the effective way to improve their performance in improving the learning process. The principal use persuasive approach to suggest the low performance teachers, strict behavior and character to improve their performance; and (3) The obstacles faced by the principal in improving the teachers' performance are: lack of budget for teacher's training out of the official duty hour, inactive teachers, and the training result which has not socialized yet.
\end{abstract}

Keywords: Managerial competence, principal, and teacher's performance

\section{Introduction}

All teachers are demanded to have active roles in doing their obligations as education workers in teaching the children of the nation. To their obligations well is actually a demand by the principal as the lead manager in an education institution. In improving teacher's performance, the principal can apply various methods and leadership style depending on the problems or personality faced by the principal. When the capability, willingness, and personality are at the good state then all efforts will affect positively to the institution. In his 
capacity as the leaders of education institution, a principal is demanded to choose strategies or leadership styles which are suitable to be implemented by helping everyone with the professions as teachers to have better performance. The inappropriate implementation of strategies or leadership style done by the principal will affect negatively to institution development. There are obstacles faced by the principal in improving teacher's performance. This can be ignored that the efforts in improving teachers performance will be disrupted and affect seriously the learning process quality. These are the reasons that ignite the researcher to conduct a study entitled "The Principal Managerial Competence in Improving Teachers Performance at State Junior High School 1 and State Junior High School 13 of Banda Aceh."

\section{Research Method}

The method used in this study is descriptive with a qualitative approach. [1] states that "qualitative data is data with the form of words, sentences, body moves, face expression, chart, and pictures". The subjects of this research are the principals, vice principal in the curriculum affairs, art and culture subject teachers, and students. The variable in this research is one independent variable which is managerial competence and one dependent variable which is teachers performance. Data collection techniques are observation, interview, and documentation. [1] adds that, "data collection can be conducted in various settings, various sources, and various ways". When we look at the setting this research, it can be seen that the data were collected on the natural setting which are on the laboratory with the experiment method, at school to teachers and school administrative staff, at home to various respondents, in a seminar, discussion, on the streets and many else. The collected data then and information from the previous related research were analysed and interpreted from the beginning of the research until the end of the research by sticking to the theoretical frame related to the problems being studied. The data analysis in this qualitative research was conducted by grouping, referring, omitting the unimportant parts, data reduction, concluding the main topics (data display) and drawing conclusion (data verification).

\section{Result and Doscussion}

\subsection{The concept of Principle Strategies}

Strategy means a clear plan made to achieve any particular goals. According to [2] "The terms strategy, method or technique are often used tau interchangeably although the fact that all these terms have different meanings." The good characteristic of strategic management is the capability of supporting the organization mission, utilizing the opportunity and strength, neutralizing the treat and overcoming the weakness, so that the objectives of the organization can be achieved. Management and strategy are a number of decisions and actions in designing a good strategy for helping people to reach the goals of any particular organisation they work. Strategy in leading is one of the factors in determining whether the organization is going to well or not. Leadership is a process of influencing a group as an effort of formulating the next objectives. Leadership is the first step to solve the problems and it has to be interactive and consistent. 


\subsection{Roles and Function of Principal}

The principals are actually school functional workers who have the mandate to lead schools programs and activities. Thus the composition of principals duties weight on principals duties, not on the teaching-learning process. In the institution level like school, education leadership can be seen in the limited coverage of the institution which is the principal, while in the technical level, teachers are the ones who are responsible. Every leader should consistently run the leadership well. The policy decided and implemented by a principal are actually the political product in education. "A principal has an important role in improving education quality" Based on the quotation mentioned earlier, it shows that a principal has a great role in improving the quality of education institution he/ she leads. The principal in education management paradigm can initiate a positive effect and principal change in renewing the education system in their school.

\subsection{Principal Leadership Style}

Leadership style is the way a leader in facing and delivering service to the various staff and subordinates who have different personalities and keep changing. People on the positions of leading should have the ability of "reading" the circumstances correctly and adjust their leadership style to the problems they face and any particular situation happening. Education leadership is the position that emphasizes on reading capability and understanding various characters, personal preferences, and traits of teachers who are actually the subordinates. This is because the teachers led by the principal certainly have different characters and personality, either in their educational background or personal background. To actually be able to supervise these teachers, a principal should adjust his or her leadership style to be used accordingly with the conditions faced by the teachers.

\subsection{Principal Program in Improving Teachers Performance}

Apart from semester programs, there are also other programs like new students administration, the school programs of principal, technical administration, learning observation, the book of curriculum technical instruction, the classroom visit observation, cooperative works with school committee, security and cooperativeness, school supplies administration, classroom observation, school inventory administration, library administration, and textbook administration where these books serve as the evidence of school activities.

The textbook administration is one important thing to focus on because it is closely related to students work capacity. The complete package of textbooks and related to the curriculum defines the development of education quality. This is due to the successful learning process which is supported wholly by the complete package of textbooks and other learning sources for teachers and students. In the importance of learning resource, [3] mentioned that: "Learning resources are everything found in the surroundings of study place which functionally can be used to let the study outcome optimal. Study optimization is not only seen from learning output, but also from the process which is students interaction with the various learning sources that can trigger students to learn in faster speed and at the same time helping students to improve their mastery of the subject they learn"

The previous quote shed a light on the definition of how importance the learning source is as a significant point in improving students learning outcome. The result of the study also shows that in the principal leadership to improve teachers performance, the principals have formulated the written plan. However, the planned programs are found to be incomplete and vague without necessary details. The principal leadership improves the teacher's performance by formulating the programs. However, not all the programs are written in detail and complete. This condition causes the planned programs to be implemented well by the 
principals in both schools of State Junior High School 1 and State Junior High School 13 of Banda Aceh. The result of the study shows that in improving teachers' performance, the principals have done various positive efforts in formulating the programs. Then the programs are shared with teachers so that teachers understand their main duties and functions in accordance to the regulation and school vision. This emphasizes that principal's role as the leaders of the institutions are significant in uplifting the work outcome of the staff in the place. [4] elaborate that "The principal role which seems to be bigger than others are academically legal. The references that state that school can be organized by a principal and a principal as a lead role have been written in numerous studies. However, the bureaucracy often seems to appear with some obstacles that discourage principal creativity.

\subsection{Principal Strategy in Improving Teachers Performance}

The type of the strategy used by the principal in defining the job description to all teachers is through the most democratic ways possible. Then the principal advice all teachers to do their obligations assigned to them well. Teachers responsibility in doing their tasks vary from one task to another. Some teachers are not satisfied when they do not finish their jobs well, while some others just complete their tasks for the sake of finishing the tasks only.

The leadership of principal can be started and run democratically, however when teachers do not do their tasks responsibly, a principal with his full responsibility may address the problem in sort of otoritic ways. Thus a principal should consistently supervise and guides teachers to do their tasks well and completely.

In the attempt to improve teachers performance, a principal should always implement democratic leadership because this type of leadership allows teachers to feel accepted and not feeling as if they are just the subordinates that can be ordered by their leader at any time. IN fulfilling the role of leadership, democratic principals have the belief that people like it to be directed. Being the workers with the assigned job description and being guided to solve the problems faced by taking any decision with full responsibility. Therefore, the subordinates in the democratic environment are not suitable to be assigned with the responsibility to design their works initiative or any activities that emphasize on creativity.

Based on the previous explanation, it shows that a principal that implement democratic leadership is preferred by the teachers in that school they work. This is what we can see from the principals in State Junior High School 1 and State Junior High School 13 of Banda Aceh. The principals adhere to the leadership style of negative which means the leaders allow the subordinates, the teachers, to have chances and authority to solve their own problems. By allowing teachers to have the authority significantly it will increase teacher responsibility in completing their tasks. Works discipline is someone mental and emotional reaction towards their job. When a leader aspires his or her subordinates to improve their work discipline, he or she needs to take the subordinates welfare in to account which means their necessity and work comfort. By showing a great example in discipline, it means the principal guides the teachers in forming their characteristics and traits to actually respect their colleagues.

Their things need to be emphasized by the principal when he or she is willing to improve teachers discipline. [5] states that there are few things a principal needs to concern in improving teachers discipline, which are: (1) Helping and guiding teachers in developing their attitude patterns, (2) helping teachers improving their attitude standards, and (3) utilizing the implementation of rules as tools. Moreover, he states that the importance of teachers discipline in improving: respects towards authority, the efforts in building cooperativeness between teachers, the needs of being involved in organization, and respect towards others. The explanation above shows that the principals of State Junior High School 1 and State Junior High School 13 of Banda Aceh have applied the leadership strategy with the examplary pattern to improve teachers performance. If there are teachers who often come late to work, 
the principals need to apply more firm leadership to remind the teachers directly and to supervise the attendance to the class and on paper. This means that the leadership applied by the principals is already effective so that the teachers discipline are under control and they can avoid doing the same mistakes in future. By implementing the discipline, teacher performance can be conducted perfectly as what it is intended.

\subsection{Obstacles Faced by the Principals and Their Follow-Up Attempts in Improving Teachers Performance}

The data analysis shows that there are some obstacles faced by the principals in planning. The Annual Work Program which consists of a couple of sub category with general description, are not implemented optimally so far. These programs were not run well, merely because the lack of budget both in State Junior High School 1 and State Junior High School 13 of Banda Aceh. One of the excellent programs to improve teachers performance is teachers training program and teachers involvement in the activity of Discussion of Subject Teachers (Musyawarah Guru Mata Pelajaran-MGMP). Every year, all the programs are planned, but they are not effectively run because of the lack of transport fee for the teachers to attend the trainings. Not to mention the number of teachers who attend the MGMP discussions may be more than two for each semester.

The obstacles faced by the principals in supervising teachers in mastering the education foundation and the implementation of teacher performance improvement is the lack of budget for teachers to have trainings out of their working hours. There are still teachers who are not active in spreading the result from the trainings they attended and the seminars result is not optimally benefitted other teachers. This illustrate that a small number of teachers in State Junior High School 1 and State Junior High School 13 of Banda Aceh are not capable yet in mastering the education foundation which then affect to their working performance especially in running the teaching-learning process in schools. Thus every teacher who does not master the education foundation yet, will face some difficulties in teaching and supervising their students at schools. There are three aspects that a school needs to develop. They are professionalism, career coaching, and welfare. This is in line with the statement of [6] as mentioned below:

The professional teachers should always be creative and productive in creating some education innovation to enhance education quality. However, preparing innovative teachers is not hard when it correlates with the factor of teachers' welfare system in Indonesia which is far from sufficient. Teachers professionalism in education institution can be enhanced by improving work motivation or work productivity, and by allowing teachers to take some trainings and education profession.

As it is in line with the above quotation, it can be understood that the process of making qualified teachers can be accelerated by letting teachers involve in trainings and professional education. Improving human resource is through: "selection stage, assigning stage, placement stage, environment adjustment stage and career development stage. However, to improve personal career, teachers can take some education process through trainings and supervision.

There is also obstacle in teachers' capability in formulating the lesson plans. This obstacles faced by both parties, teachers and principal. For teachers, they have no willingness to improve the lesson program or lesson plans. They tend to stick to previous year program with minor revision made. As for the principal, time constraint to check the lesson plans is the obstacle. This illustrate that the improvement of teacher performance were not run well.

Another obstacle faced by the principals are time constraint in supervising teachers as the attempt to recover and supervise to improve teachers performance. This time constraint is due to principal tight schedule like general meetings, solving financial problems, and doing some activities of the programs planned by the school committee and students' parents. Therefore, this 
task of teacher supervision was then mandated to vice principal and senior teachers. Though they actually conducted the supervision in the learning activities in class by using observation sheet, they did not seem to improve and overcome their problems in learning activities to be optimal. [7] mentions that "To achieve the objectives of education and learning, assessment and evaluation are needed to be done." Assessment or evaluation are actually the acts of evaluate something with any particular criteria. As for the objectives of leanings, they are mentioned in characters that students need to build during the learning experience.

Teachers' supervision in teaching-learning process aim to enhance and guide teachers' capability and skills as part of teachers performance. Because the principal has limited time in doing so, the vice principal and senior teachers are authorized to to the job. However, the works are not satisfying since it was not done well. Anytime there are cases on the ground or obstacles appear among the teachers in fulfilling their functions, the principals in both schools, State Junior High School 1 and State Junior High School 13 of Banda Aceh, did not handle them right away. Professional teachers should always be creative and productive in making some innovation in education to actually improve the education quality. To be creative means that a teacher needs to prepare various materials. It means that it is hard to an innovative teacher because it is related to teachers financial state. The system of teacher welfare and teachers certification in Indonesia is not optimal yet.

\section{Conclusion}

1. The principal programs as the effort to improve teachers performances have been planned and arranged in every year around. However, they are not in detail and correct yet. The planned programs are conducted anyway, with an optimal effort, by the principal in order to improve the motivation and work ethics of the teachers.

2. The implementation of planned program in improving teachers work performance is by applying the democratic strategy in leadership. In facing the teachers, the principal is open up to discussion with the teachers, so that there will be the effective way in improving teachers performance in order to develop the teaching-learning to be better.

3. The obstacle faced by the principal in improving teachers performance are actually the lack of budgeting for financing teachers to take trainings out of their working hours. Besides the knowledge the teachers accepted in the training are not transferred completely among the colleagues in the school.

\section{Suggestion}

1. Programs of principals in State Junior High School 1 and State Junior High School 13 of Banda Aceh in improving teachers performance were not effective yet, especially in the finance management. It needs to be fixed by designing a detail program, so that the performance improvement can become true and permanent.

2. The principal strategy in improving teachers performance utilize more than more than one style in leadership, so that a teacher can improve their teacher performance, responsibility, and motivation. The principal needs to be detailed in determining teachers who need to be supervised more with the right strategy, so the teacher improvement can be right on the target planned.

3. There are obstacles in the budgeting especially for teacher trainings, so that the principal ideally tries another solution like holding the Discussion of Subject Teachers 
(Musyawarah Guru Mata Pelajaran-MGMP) located in the school. This effort will allow the school to minimize the expense and will positively affect the improvement of teachers performance in State Junior High School 1 and State Junior High School 13 of Banda Aceh.

\section{Reference}

[1] Sugiyono, Memahami Penelitian Kualitatif. Bandung: Alfabeta, 2013.

[2] H. B. Uno, Model Pembelajaran Menciptakan Proses Belajar Mengajar yang Kreatif dan Efektif. Jakarta: Bumi Aksara, 2012.

[3] W. Sanjaya, Perencanaan dan Desain Sistem Pembelajaran. Jakarta: Kencana, 2012.

[4] Danim and Suparno, Menjadi Pemimpin Besar Visioner Berkarakter. Bandung: Alfabeta, 2012.

[5] E. Mulyasa, Manajemen Kepemimpinan Kepala Sekolah. Jakarta: Bumi Aksara, 2011.

[6] A. Hadis and Nurhayati, Manajemen Mutu Pendidikan. Bandung: Alfabeta, 2012.

[7] Sudjana, Penelitian dan Penilaian Pendidikan. Bandung: Sinar Baru, 2011. 